先天性鼻咽腔閉鎖不全症の鼻副鼻腔疾患

$\begin{array}{ll}\text { 石川 保之・森 } & \text { 一功* } \\ \text { 川野 通夫*・本庄 蘩* }\end{array}$

\title{
Nasal Diseases in Patients with Congenital Velopharyngeal Insufficiency
}

\author{
Yasuyuki Ishikawa \\ (Nagahama Red Cross Hospital) \\ Kazunori Mori, Michio Kawano and Iwao Honjo \\ (Kyoto University)
}

Several investigators have reported a high incidence of middle ear diseases in patients with congenital velopharyngeal insufficiency (CVPI). However, little is known about nasal diseases in these patients. In the present study, we examined the incidence of intranasal deformities and nasal sinusitis. Nasal airway resistance was determined by the active-anterior method. A history of allergic disease and eosinophils in nasal secretions were sought for in the patients with nasal sinusitis. The incidence of chronic middle ear diseases was also correlated with that of nasal sinusitis.

1) A high incidence $(55.9 \%)$ of nasal sinusitis was noted in patients with CVPI under 15 years of age.

2) The incidence of intranasal deformities, such as deviation of the nasal septum and hypertrophy of the inferior turbinate, was low in patients under 15 years of age.

3) Few patients had abnormaly high nasal airway resistance.

4) Allergy was thought to contribute little to the development of nasal sinusitis in these patients.

5) Chronic middle ear diseases in these patients showed a close correlation with the presence of nasal sinusitis.

Key words: congenital velopharyngeal insufficiency, sinusitis, intranasal deformity, nasal airway resistance, middle ear disease

はじめに

口蓋裂を伴わず先天的に開鼻声と口蓋裂言語 同様の構音障害を示す例は先天性鼻咽腔閉鎖不 全症 (congenital velopharyngeal insufficiency,
以下, CVPI と略す) と総称される. CVPI では 中耳疾患の罹患率が高いとするもの $\left(42.0 \%{ }^{1)}\right.$, $32.3 \% \%^{2)}, 20.0 \%{ }^{31}$ ), 低いとするもの $\left(5.6 \% \%^{4)}\right)$ があるが，CVPI の鼻副鼻腔疾患については我 
我が調査し得た範囲では，星野ら ${ }^{5)}$ の報告のみ である。そこで, 今回, CVPI における鼻副鼻腔 疾患, 特に副鼻腔炎の頻度や特徵を調へ，副鼻 腔炎と中耳疾患との関連についても検討した。

\section{対象亡方法}

CVPI 36例（年齢2～19歳）(図 1 ). CVPI の 診断は, 視診上, 口蓋裂, 粘膜下口蓋裂の所見 がなく，かつ鼻咽腔閉鎖不全を示す症例で，う ち，軟口蓋の長さが短い，咽頭腔が深いなど解 剖学的異常例と, 咽頭側壁, 軟口蓋の運動不良 例とが含まれる。乙れら症例の鼻咽腔閉鎖機能 の判定は音声の聴覚的判定, ニューモタコグラ フィー，鼻咽腔ファイバースコピー，レ線造影 ビデオ検査により行った。 コントロール群とし て，検診を行った正常人1743名（年齢3～19歳） と当科受䛦の副鼻腔炎例 81 名(年齢 $3 \sim 13$ 歳)を 用いた。

$<$ 検討項目と方法 $>$

1 ) 副鼻腔炎之鼻腔形態

(1)副鼻腔炎：CVPI 小坚例 34 名（年齢 $2 \sim 13$

歳）に対して前鼻鏡検査，必要により鼻レ線撮 影を行い副鼻腔炎の有無を調べた。一方, 正常 コントロール小児1625名（年齢 $6 \sim 14$ 歳）に対 して前鼻鏡検査を行い副鼻腔炎の有無を調べた。 (2)鼻中隔弯曲之下甲介肥大：同じくCVPI 小 児例 34 名 (年齢 $2 \sim 13$ 歳), 正常コントロール 小児1625名（年齢 6 ～14歳）について前鼻鏡検

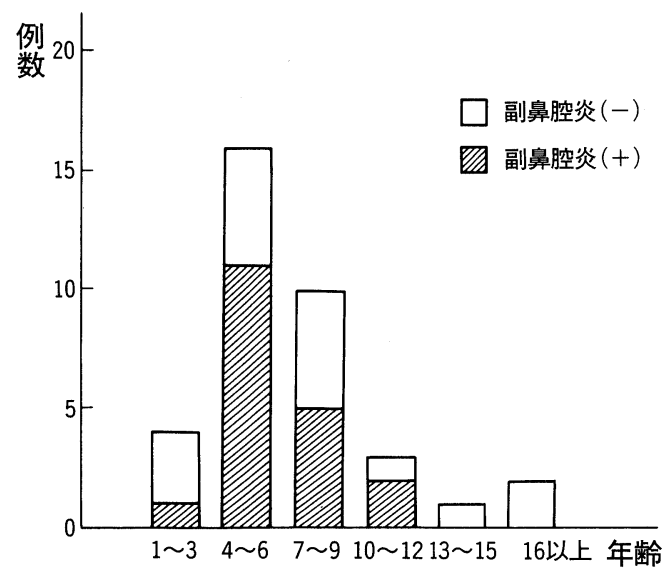

図 1 CVPI 例の年齢分布
査を行い，鼻中隔弯曲と下甲介肥大の有無を調 べた.

2）鼻腔通気度検査

CVPI 例22名(年齢 4 〜 19歳) と正常コントロ ール558名 (年齢 3 〜 19歳) について，リオン鼻 腔通気度計 SR-10 により, 坐位, 室温での鼻腔 通気度検查を行った。測定は active-anterior 法 （マスク法）により，吸気で圧差が 100 パスカル の時の総合鼻腔抵抗值を記録した．年齢別に正 常人の平均值 $\pm 2 \mathrm{SD}$ を算出し正常範囲とした.

3 ) 副鼻腔炎に打けるアレルギーの関与と臨 床病型

(1)アレルギーの関与 : CVPI 小览副鼻腔炎例 13名（年齢 $2 \sim 11$ 歳）と正常コントロール小児 副鼻腔炎例81名（年齢 $3 \sim 13$ 歳）について，喘 息，アレルギー性鼻炎，アレルギー性結膜炎， アトピー性皮膚炎, 薬物と食物アレルギーの既 往歴の有無を調べた.

CVPI 小览副鼻腔炎例 7 名(年齢 $4 \sim 7$ 歳) と 正常コントロール小览副鼻腔炎例81名（年齢 3 １3歳）につき鼻汁中好酸球を塗沫染色 (Eosinostein (Hansel)-TORII-，1 分間法) で調べ, 表 1 の基準により 4 段階で評価した.

(2)臨床病型：CVPI 小児副鼻腔炎例19名（年 齢 2 12歳）と正常コントロール小览副鼻腔炎 例81名（年齢 $3 \sim 13$ 歳）について副鼻腔炎の臨 床病型を調べた。臨床病型は前鼻鏡所見, 鼻レ 線でビマンカタル型, 限局感染型, 浮腫茸状型 に分類した (名越の分類6).

4 ）副鼻腔炎之中耳疾患

CVPI 全例36名について副鼻腔炎の有無之中

表 1 鼻汁中好酸球の判定

\begin{tabular}{c|l}
\hline $\begin{array}{c}\text { 鼻计中の好 } \\
\text { 酸球の程度 }\end{array}$ & \multicolumn{1}{|c}{ 判 定 基 準 } \\
\hline$(+H)$ & 多数認められ集塊を形成している \\
$(+)$ & (H+)と（+）の中間 \\
$(+)$ & 散見される程度 \\
$(-)$ & 認められない
\end{tabular}


耳疾患（滲出性中耳炎と慢性中耳炎）との関係 を調べた。

\section{結 果}

1) (1)CVPI 小児例では正常コントロール小 児に比して副鼻腔炎の罹患率が有意に高いこと がわかった $(\mathrm{P}<0.01)$ (図 2$)$.

(2)鼻中隔弯曲と下甲介肥大の頻度は両群間で 有意差を認めなかった（図 3，4）.

2) CVPI 例の鼻腔抵抗值では 22 例中 5 例 （約22.7\%）が異常高值を示した（図 5 ). 副鼻 腔炎のない CVPI 例では11例中 1 例(約9.1\%)

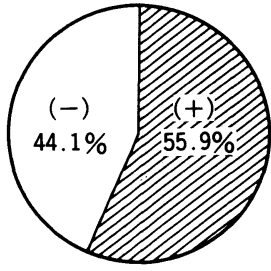

CVPI小児

$(2 \sim 13$ 藏 $N=34)$

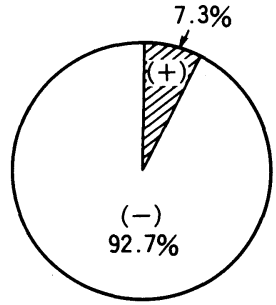

正常小児 $(6 \sim 14$ 效, $N=1625)$
図 2 副鼻腔炎の有無

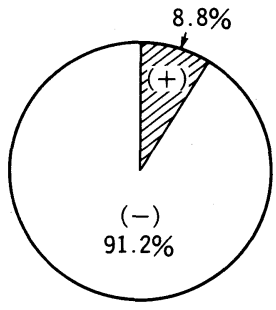

CVP小小児

(2 13歳, $N=34)$

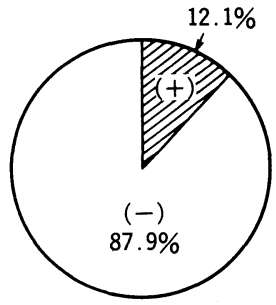

正常小児

(6〜14歳, $N=1625)$
図 3 鼻中隔弯曲の有無

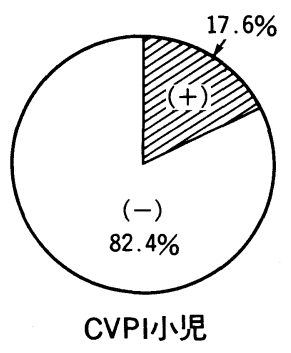

(2 13歳, $N=34)$

図 4 下甲介肥大の有無
が異常高值であった.

3) (1)CVPI 小巟副鼻腔炎例では正常コント ロール小児副鼻腔炎例よりアレルギー疾患の既 往歴が有意に少なかった $(\mathrm{P}<0.02)$ (表 2$)$.

鼻汁中好酸球 (H) 異常の頻度は両群間で有 意差を認めなかった（表 3 ）.

(2)CVPI 小児副鼻腔炎例では正常コントロー ル小児副鼻腔炎例より限局感染型が有意に多か った $(\mathrm{P}<0.02)$ (表 4$)$.

4 ) CVPI 全例で中耳疾患は，滲出性中耳炎 9 例 (25.0\%)，慢性中耳炎 4 例 (約11.1\%), 両者を持つもの 1 例 (約 $2.8 \%$ ) であった. また，

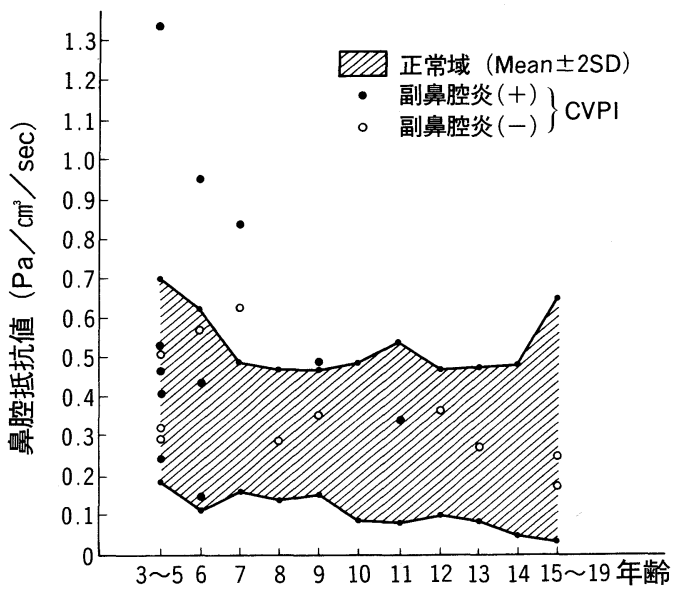

図 5 active-anterior 法による鼻腔抵抗值

表 2 アレルギー疾患既往の有無 $(\mathrm{P}<0.02)$

\begin{tabular}{c|c|c}
\hline \hline $\begin{array}{c}\text { アレルギー疾 } \\
\text { 患既往の有無 }\end{array}$ & $\begin{array}{c}\text { CVPI } \\
\text { 小监副鼻腔炎例 }\end{array}$ & $\begin{array}{c}\text { 小正常 } \\
\text { 小副鼻腔炎例 }\end{array}$ \\
\hline 有り & 1 & 38 \\
無し & 12 & 41
\end{tabular}

表 3 鼻汁中好酸球

\begin{tabular}{c|c|c}
\hline 鼻汁中好酸球 & $\begin{array}{c}\text { CVPI } \\
\text { 小坚副鼻腔炎例 }\end{array}$ & $\begin{array}{c}\text { 小正常 } \\
\text { 小副鼻腔炎例 }\end{array}$ \\
\hline$(+)(H)$ & 1 & 30 \\
$(-)(+)$ & 6 & 51
\end{tabular}


副鼻腔炎をもつ例は有意に高率に中耳疾患を之 もなっていた $(\mathrm{P}<0.05)$ （表 5 ).

\section{考察}

CVPI の鼻副鼻腔疾患に関する報告では，星 野ら ${ }^{5)}$ が咽頭弁形成術を行った CVPI 例の10.9 \%に副鼻腔炎を報告しているのみである.今回 の調査では CVPI 小览例の半数以上(約 $55.9 \%$ ), に副鼻腔炎を認め，乙の值は口蓋裂例の副鼻腔 炎の頻度之ほぼ等し( ${ }^{778)}$. 今回, CVPI 小児例 では鼻中隔弯曲や下甲介肥大などの鼻腔形態異 常の頻度は正常人之差がなく，鼻腔抵抗值屯正 常のものが多いととがわかったが，先の我々の 調查 ${ }^{7)}$ では，口蓋裂例では鼻腔形態異常を高率 に伴い，鼻腔抵抗異常高值例も多いことが確認 されている，鼻腔の通気性と鼻腔粘液線毛機能 とは密接な関係があり ${ }^{9)}$ ， 口蓋裂例では鼻腔の 形態異常と鼻内気流異常とが鼻腔粘液線毛機能 障害を招き，副鼻腔炎を来す可能性があるが10) 鼻腔形態異常の少ないCVPI の副鼻腔炎多発の 原因は口蓋裂のそれとは異なるものと推測され た.

今回，CVPI での高率な副鼻腔炎合併の原因 解明の一助として, CVPI の副鼻腔炎を, アレル ギーの関与と臨床病型の 2 点で検討した。 その

表 4 副鼻腔炎の臨床病型 $(\mathrm{P}<0.001)$

\begin{tabular}{|c|c|c|}
\hline 臨 床 病 型 & $\begin{array}{c}\text { CVPI } \\
\text { 小児副鼻腔炎例 }\end{array}$ & 小先副常腔炎例 \\
\hline $\begin{array}{l}\text { ビマンカタル } \\
\text { 型 }\end{array}$ & $8(42.1 \%)$ & $67(82.8 \%)$ \\
\hline 限局 感染 型 & $11(57.9 \%)$ & $13(16.0 \%)$ \\
\hline 浮腫茸状型 & $0(0 \%)$ & $1(1.2 \%)$ \\
\hline
\end{tabular}

表 5 副鼻腔炎之中耳疾患（滲出性中耳炎, 慢性中耳炎 $) \quad(\mathrm{P}<0.05)$

\begin{tabular}{|c|c|c|}
\hline $\begin{array}{l}\begin{array}{r}\text { 中耳疾患 } \\
\text { の有無 }\end{array} \\
\text { 副鼻腔炎 } \\
\text { の有無 }\end{array}$ & 有り & 無 し \\
\hline 有 り & 11 & 8 \\
\hline 無 し & 3 & 14 \\
\hline
\end{tabular}

結果, CVPI の副鼻腔炎では正常人の副鼻腔炎 に比してアレルギー疾患の既往歴の頻度が有意 に少なく，また，鼻汁中好酸球（H）以上の例 は CVPI 副鼻腔炎例では約14.3\%と低率であり， アレルギーの関与は少ないことがわかった。ま た，副鼻腔炎の臨床病型では，CVPI では限局 感染型が有意に多いことがわかった。名越 ${ }^{11}$ ， 梅沢 ${ }^{12)}$ は限局感染型は局所的素因が強く関与し ていると述べており，今後は，局所的要因の検 討が必要であろう。

さて，副鼻腔炎と中耳疾患との関連について の報告 ${ }^{131414)}$ は多く，今回の CVPI の観察で屯 副鼻腔炎を毛つ例の中耳炎の合併率は高率（約 57.9\%）であった。中耳疾患は主に滲出性中耳 炎であったが，滲出性中耳炎例では上咽頭の菌 検出率が高く ${ }^{15)}$ ， 上咽頭と中耳滲出液中の菌の 一致率が高いとと ${ }^{16) 17)}$ 等が知られて抢り，今回 の観察結果でも，CVPI に伴う中耳炎が鼻副鼻 腔の細菌感染波及による可能性が考えられた.

\section{まとめ}

先天性鼻咽腔閉鎖不全症 (CVPI) の鼻副鼻腔 疾患の頻度や成因について検討し，さらに中耳 慢性炎症疾患との関連についても調べた。

1 ） CVPI 小览例では副鼻腔炎罹患の頻度は 55. $9 \%$ と高率であった。

2) CVPI 小児例の鼻腔形態異常は少なく, 鼻腔抵抗の異常高值例屯少なかった。

3 ) CVPI の副鼻腔炎の発症にアレルギーな どの体質的要因の関与は少なく，むしろ局所的 要因が大きいと考えられた。

4) CVPI に打ける中耳慢性炎症疾患多発は 鼻副鼻腔炎の波及が一因である可能性が考えら れた。

\section{参考文献}

1) Caldarelli DD : Incidence and type of otopathology associated with congenital palatopharyngeal incompetence. Laryngoscope 88: 1970 1984, 1978.

2) Durr DG and Shapiro RS : Otologic manifestations in congenital velopharyngeal insufficiency. 
AJDC $143: 75 \sim 77,1989$.

3 ）矢部利江，阿部雅子，澤島政行：口蓋裂及び先天 性鼻咽腔閉鎖不全症患者における滲出性中耳炎一 臨床的観察一. 日耳鼻 $92: 1012 \sim 1020 ， 1989$.

4) 田坂康之：口蓋裂例の中耳疾患之耳管の病態. 耳 鼻臨床 $82 ： 1155 \sim 1167,1989$.

5 ）星野鉄雄, 納 一功, 木村 照: 先天性鼻咽腔閉 鎖不全症における副鼻腔炎. 音声言語 $29: 87$ 88, 1988.

6 ）名越好古, 金子善一, 梅沢重一, 他 : 慢性副鼻腔 炎の自然変動に対する発言. 耳展 9 補 4:402 407, 1966.

7 ）石川保之：口蓋裂例の鼻副鼻腔疾患.耳鼻臨床 $82:$ 995 1015, 1989.

8 ) Ishikawa Y, Kawano M, Honjo I, et al : The cause of nasal sinusitis in patients with cleft palate. Arch Otolaryngol Head Neck Surg 115 : 442 $\sim 446,1989$.

9 ) Doyle WJ : Relationship between nasal patency and clearance. Rhinology $25: 167 \sim 179,1987$.

10）石川保之, 川野通夫 : 口蓋裂例の鼻副鼻腔疾患一 文献的考察一. 耳鼻臨床 $83: 1093 \sim 1098,1990$.

11）名越好古：小监副鼻腔炎の変遷と対策. 耳喉 50
: 539 544, 1980.

12）梅沢美和子：小児期副鼻腔炎の予後に関する研究. 耳展 17 補 $1: 5 \sim 23,1974$.

13) Grotte JJ and Kuijipers W : MiddJe ear effusion and sinusitis. J Laryngol $94: 177 \sim 183,1980$.

14）古和田勲：小児副鼻腔炎亡中耳炎. 耳喉 52 : 559 〜56, 1980.

15) Sundberg L, Cederberg A, Eden T, et al : Bacteriology in secretory otitis media. Acta Otolaryngol Suppl $384:$ 18 25, 1981.

16) Kamme $C$ and Nilsson $N$ : Secretory Otitis media ; microbiology of the middle ear and the nasopharynx. Scand J Infect Dis $16: 291 \sim 296,1984$.

17) Mills RP, Uttley AHC and Mclntyre MF : A bacteriological study of the middle ear and upper respiratory tract in children with chronic secretory otitis media. Clin Otolaryngol $10: 335 \sim 341$, 1985.

原稿受付 : 平成 2 年 3 月 13 日

原稿採択：平成 2 年 4 月 12 日 別刷請求先 : 石川保之 干526 長浜市宮前町14-7 長浜赤十字病院耳鼻咽喉科 